TITLE Detoxification of Hazardous Waste Streams Using Microwave-Assisted Fluid-Bed Oxidation

AUTHOR(S): Ravi Varma

S. P. Nandi

Joel D. Katz

SUBMITTED TO: For Publication in the Symposium Volume for the 1990

Spring Meeting, Materials Research Society,

April 16-21, 1990, San Francisco, CA.

\title{
DISCLAIMER
}

This report was prepared as an account of work sponsored by an agency of the United States Government. Neither the United States Government nor any agency thereof, nor any of their employees, makes any warranty, express or implied, or assumes any legal liability or responsibility for the accuracy, completeness, or usefulness of any information, apparatus, product, or process disclosed, or represents that its use would not infringe privately owned rights. Reference herein to any specific commercial product, process, or service by trade name, trademark, manufacturer, or otherwise does not necessarily constitute or imply its endorsement, recommendation, or favoring by the United States Government or any agency thereof. The views and opinions of authors expressed herein do not necessarily state or reflect those of the United States Government or any agency thereof. 


\section{DETOXIFICATION OF HAZARDOUS WASTE STREAMS USING MICROWAVE-ASSISTED FLUID-BED OXIDATION}

R. Varma, ${ }^{*}$ S.P Nandi, and J.D. Katz**

Argonne National Laboratory, Argonne, Illinois 60439

* Present Address: Los Alamos National Laboratory, Los Alamos, New Mexico 87545

* * Los Alamos National Laboratory, Los Alamos, New Mexico 87545 


\begin{abstract}
Microwave-assisted oxidation of trichloroethane (TCE) performed at 500$580^{\circ} \mathrm{C}$ has been found to be significantly more efficient than conventional oxidation methods. Experiments were conducted using a $6 \mathrm{~kW}, 2.45 \mathrm{GHz}$ power supply and a 6 inch bed of silicon carbide granules in a 1 inch diameter quartz reactor tube which in turn was placed in a microwave cavity. After heating the reactor to a given temperature a TCE-air stream was passed through the silicon carbide bed. TCE was almost completely detoxified (98-99\%) in a single pass through the silicon carbide bed at 500$580^{\circ} \mathrm{C}$. The oxidation products are $\mathrm{HCl}, \mathrm{CO}_{2}$ and $\mathrm{CO}$. By comparison the corresponding single-pass detoxification using conventional thermal methods results in only partial conversion. The principal products being dichloroethylene $\left(\mathrm{C}_{2} \mathrm{H}_{2} \mathrm{Cl}_{2}\right)$ and $\mathrm{HCl}$.
\end{abstract}

\title{
Introduction
}

State-of-the-art detoxification of halohydrocarbons is conducted by high temperature $\left(>1200^{\circ} \mathrm{C}\right)$ incineration in air or oxygen stream. However, corrosion problems are severe, and control of the time-temperature parameter in the combustion zone to avoid PICs (products of incomplete combustion, including dioxines) may be difficult to achieve in practice.

Microwave heating for combustion at $1000^{\circ} \mathrm{C}$ of radioactivity contaminated inn-exchange resins in low-level mixed wastes has been reported by Nahomi et al. ${ }^{1}$ We report here novel microwave-assisted surface effects that may be responsible for enhanced reactions observed in the case of oxidation of TCE by air at silicon carbide surfaces, in a packed or fluid bed of the same material.

\section{Experiments and Results}

A one-inch diameter quartz tube with a fritted quartz disk on which the bed material $(60$ by 80 mesch technical grade silicon carbide) rested was used for both microwave and thermal runs. The settled bed height of 6 inches and two flow rates of air were used in the oxidation experiments. In the case of microwave runs, the bed temperature was maintained by dielectric heating by $2.45 \mathrm{GHz}$ microwaves. The bed was viewed through an opening in the cavity by using an infrared pyrometer (IRCON 6000 Series) for temperature measurement. In thermal runs, the same bed was electrically heated using a long (18-inch) tube furnace. Both the infrared pyrometer and the thermocouple sensors used in monitoring the bed-temperature in the thermal furnace were calibrated with a standard test furnace. Air-TCE gas mixtures were passed through the packed or fluid bed of silicon carbide, energized to the same temperature by dielectric-loss and thermal heating. Before we began a detoxification run, the TCE in the 
carrier gas was adsorbed by a preweighed active carbon bed at $0^{\circ} \mathrm{C}$, bypassing the reactor itself. The increase in weight of the carbon bed gave a reliable measure of the feed rate in an actual experiment.

Thermal runs were conducted at $500^{\circ}, 550^{\circ}$, and $580^{\circ} \mathrm{C}$. For microwave runs, five temperatures $-400^{\circ}, 450^{\circ}, 500^{\circ}, 550^{\circ}$, and $580^{\circ} \mathrm{C}$-- were used. Two air flow rates, 252 and 510 $\mathrm{cc} / \mathrm{min}$, were used.

The product gases, after passing through the gas sampling loop, were adsorbed in $1 \mathrm{~N}$ $\mathrm{NaOH}$ solution, and the quantity of $\mathrm{HCl}$ evolved over 30 minutes was determined quantitatively. Detoxification was defined as the percentage of the chlorine determined as $\mathrm{AgCl}$ divided by the feed chlorine in TCE.

In a typical run, $98 \%$ or more of TCE was detoxified over a packed silicon carbide bed at $500^{\circ} \mathrm{C}$ using microwave heating with an air flow rate of $252 \mathrm{cc} / \mathrm{min}$. The corresponding figures for thermal runs were much lower. The results of microwave and thermal runs conducted at the bed temperature of $500^{\circ} \mathrm{C}$ are given in Table I. The results obtained over a wide range of temperatures, $400^{\circ}$ to $580^{\circ} \mathrm{C}$, for both microwave and thermal runs show that under microwave activation, a much higher degree ( $>98 \%$ ) of oxidative degradation of TCE clearly is obtained than in thermal $(\leq 36 \%)$ runs. For example, the $C-C$ bond is readily cleaved with microwave heating, but it remains intact in the case of oxidation conducted with thermal heating under the same experimental conditions.

Table I. Composition of feed and product gas for typical trichloroethane detoxification runs at $500^{\circ} \mathrm{C}$ for 30 minutes using gas flow of $252 \mathrm{~cm} / \mathrm{min}$.

\begin{tabular}{cccc} 
& \multicolumn{3}{c}{ Gas Composition (volume \%) } \\
& Feed Gas & Thermal Run & Microwave Run \\
$\mathrm{H}_{2} \mathrm{O}$ & - & $0.34 \pm 0.08$ & $0.12 \pm 0.04$ \\
$\mathrm{~N}_{2}+\mathrm{A}$ & 73.5 & $69.3 \pm 1.3$ & $64.3 \pm 1.7$ \\
$\mathrm{O}_{2}$ & 19.5 & $18.1 \pm 0.5$ & $7.5 \pm 0.2$ \\
$\mathrm{HCl}$ & - & $4.6 \pm 0.8$ & $14.5 \pm 1.5$ \\
$\mathrm{CO}$ & - & $0.0 \pm 0.0$ & $8.2 \pm 1.7$ \\
$\mathrm{CO}_{2}$ & - & $0.38 \pm 0.04$ & $5.4 \pm 0.3$ \\
$\mathrm{C}_{2} \mathrm{H}_{3} \mathrm{Cl}_{3}$ & 6.9 & $<0.3$ & $<0.04$ \\
$\mathrm{C}_{2} \mathrm{H}_{2} \mathrm{Cl}_{2}$ & 0.0 & $6.8 \pm 1.3$ & $<0.03$ \\
$\mathrm{C}_{2} \mathrm{HCl}_{3}$ & 0.0 & $<0.3$ & $<0.05$ \\
Detoxification & - & 26 & 98
\end{tabular}

"Detoxification $=(1-$ Chlorine in product gas $/$ chlorine in feed $) \times 100$. 


\section{Acknowledgement}

Support of this research by funds from the Department of Energy, Hazardous Remedial Action Program Office, Oak Ridge, Tennessee, is gratefully acknowledged.

\section{References}

1. R. Varma, "Microwave Enhanced Chemical Processes," US Patent 4,935,114, dated June 9, 1990.

2. N. Nahomi, J. Yamaji, and T. Mizushima, Paper presented at conference on incineration of low-level radioactive and mixed waste, St. Charles, IL (1987).

3. M.R. Hoare, R.G.W. Norrish, and G. Whittingham, Proc. R. Soc. A25, 197 (1959).

4. D.H.R. Barton and K.W. Howlett, L. Chem. Soc. 2033-2038 (1951).

5. A.M. Goodal and K.E. Howlett, L. Chem. Soc. 2599-2603 (1954). 

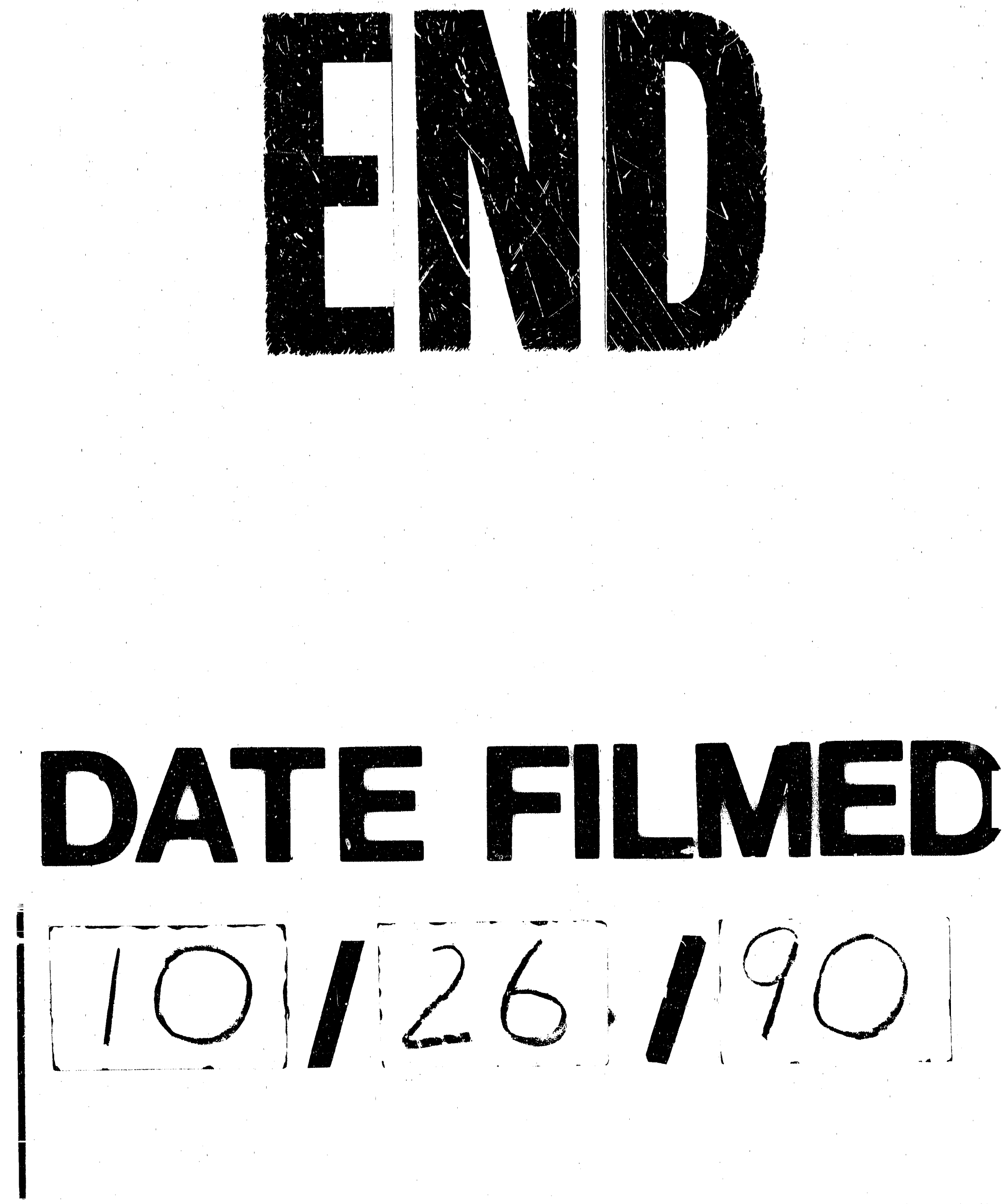
